\title{
Developing the Dimensions of a Social Content Management Framework
}

\author{
Wan Azlin Zurita Wan Ahmad", Muriati Mukhtar", Yazrina Yahya* \\ ${ }^{*}$ Center for Software Technology and Management Faculty of Information Science and Technology, \\ Universiti Kebangsaan Malaysia, 43600, Bangi, Selangor, Malaysia \\ E-mail:azlinzurita@gmail.com,muriati@ukm.edu.my \\ "Faculty of Economy and Management, Universiti Kebangsaaan Malaysia, 43600, Bangi, Selangor, Malaysia \\ E-mail: yazrina@ukm.edu.my
}

\begin{abstract}
The rise of social media has transformed the way of collaboration between organizations and customers. Social content resulting from the active collaboration between both parties on a social media platform should be managed accordingly. Thus, social content management (SCM) framework should be developed as a guide to managing the social content. Such SCM framework should be able to augment existing frameworks, which mainly focuses on the value of social content for the organizations. Hence, based on the service science perspective, this article proposes an SCM framework that focusses on value to both organizations and its customers. In order to do this, the concept of Service Dominant Logic and the DART model are adopted to explore and extract the elements and factors that collectively become the dimensions of the proposed SCM framework. Experts' review of the elements and factors is conducted to ensure that the dimensions in the SCM framework are acceptable and have practical value. The proposed framework is then validated via an instrument whose content validity is investigated by using Lawshe's Technique. This framework could assist the organizations in the decision-making process towards innovating services and in the management of social content.
\end{abstract}

Keywords - social media; social content management; service science; service dominant logic; DART model

\section{INTRODUCTION}

Social media has become a worldwide phenomenon, and it is gaining significant attention as part of the collaborative strategy between organizations and its customers. In organizations, social media becomes an active channel for communication, thus changing the way interactions are conducted between organizations and customers [1]-[3]. Social media also creates a convenient interacting medium with customers as it offers a digital transparent space [4]. A study by [5] revealed that social media interaction allows both parties to co-create content that offers services to the customers.

The importance of social media for organizations has been highlighted in several studies. A survey conducted by [6] revealed that the budget for social media-based initiatives is expected to increase due to each organization's emphasis on the power of social media. According to [7], innovation in government services is also gained through the use of social media interaction as a tool, target, and topic. [8] has also reported that social media interaction could bring innovation in the services offered by the government agencies. Additionally, [9] reported that content from social media interaction could be formed into a strategy for organizations. Besides that, [10] revealed that social media could showcase the practice of knowledge management. Therefore, content from social media interaction should be managed accordingly, in order to assist the organizations to innovate the services and creating a better engagement environment with customers (see Fig. 1).

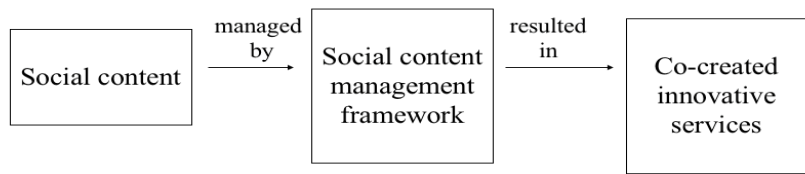

Fig. 1 Managing Social Content

Currently, the contents in organizations are managed by the enterprise content management (ECM). However, with the evolution and high volume of social contents, the ECM could not manage the content due to quality and compliance issues [11]. Thus far, social content management (SCM) was formed to manage the social content. According to [12], SCM is the dynamic management of social content, which includes data, technologies, processes, human, and organizational elements, to produce value for the business. 
Previous studies have emphasized the need to explore the elements and factors that could affect SCM [11]-[14]. According to [14], five elements could affect SCM. These are a strategy, content lifecycle, technology, governance, and change management. However, a study by [13] refined the elements based on further deliberations into the literature. Hence, a summary of the elements and factors that affect SCM which is based on a previous study in ECM according to [13] are listed in Table I.

TABLE I

ELEMENTS AND FACTORS THAT COULD AFFECT SCM [13]

\begin{tabular}{|c|c|}
\hline Element & Factor \\
\hline Strategy & None \\
\hline People & None \\
\hline Content lifecycle & $\begin{array}{l}\text { - Capturing content through interaction } \\
\text { - Managing content } \\
\text { - Analysing content } \\
\text { - Maintaining content }\end{array}$ \\
\hline Technology & $\begin{array}{l}\text { - } \text { Platform } \\
\text { - Hardware } \\
\text { - Software } \\
\text { - Repository } \\
\end{array}$ \\
\hline Governance & $\begin{array}{l}\text { - Policy } \\
\text { - Coordination }\end{array}$ \\
\hline $\begin{array}{l}\text { Strategic } \\
\text { managerial aspect }\end{array}$ & $\begin{array}{l}\text { - Management commitment } \\
\text { - Change management }\end{array}$ \\
\hline
\end{tabular}

However, viewing and developing the dimensions of an SCM framework solely on existing ECM models and frameworks would yield results that are limited in applicability. In the context of managing social content to develop innovative co-created services (see Fig. 1), the elements and factors uncovered in Table I would have to be examined from the context of service science. Hence, the main purpose of this paper is to show how this done which results in the proposed dimensions of the SCM framework based on service science perspective. The framework needs to be validated to highlight its potential. Hence, an instrument was developed based on the identified elements and factors. The content validity for all items in the instrument is validated using Lawshe's technique, namely by calculating of content validity ratio (CVR) [15].

The developed framework is expected to assist organizations in managing their social content and in the decision-making process towards innovating the services offered. The writing of this article covers; the second section is on the materials and methods used to conduct the study. The subsequent section discusses the results and discussion, and the final section concludes this article.

\section{MATERIAL AND METHOD}

This study has adopted a literature review, experts' review, and the calculation of CVR value for content validity. The research method is shown in Fig. 2.

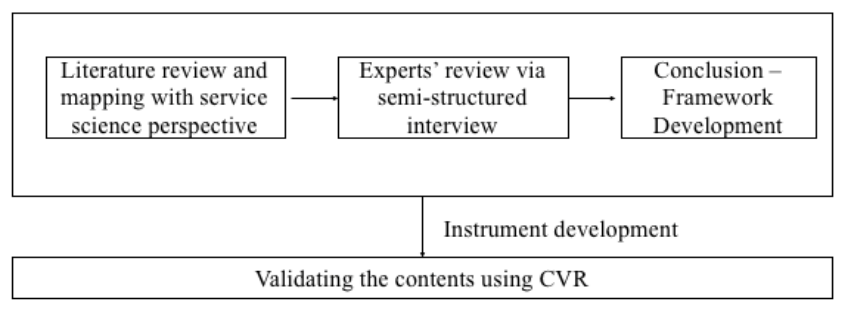

Fig. 2 Research Method

\section{A. Literature Review and Mapping with Service Science Perspective}

For the literature review, content analysis of selected papers was conducted to identify the elements and factors that could affect SCM from the perspective of service science. The criteria of the literature review process are listed in Table II.

TABLE II

CRITERIA FOR THE LITERATURE REVIEW

\begin{tabular}{|l|ll|}
\hline Criteria & Details \\
\hline Search & $\bullet$ & Research database \\
& $\bullet$ & Open search engines \\
& $\bullet$ & Reliable websites \\
\hline Keyword & $\bullet$ & Enterprise content management \\
& $\bullet$ & Social content management \\
& $\bullet$ & Service science \\
& $\bullet$ & Service Dominant Logic \\
& $\bullet$ & DART Model \\
\hline Inclusion & $\bullet$ & Academic paper \\
& $\bullet$ & Books \\
& $\bullet$ & Related report \\
\hline
\end{tabular}

The literature review critically examines the elements and factors that could affect the SCM based existing literature on ECM and SCM. The literature on service science perspective is examined to look into the possibility of using service science concepts as a platform for developing the SCM framework thus simultaneously embedding the concepts of value co-creation into the proposed framework.

\section{B. Experts' Review via Semi-Structured Interview}

Experts' review was carried out to ensure that the selected elements and factors were from the viewpoints of practitioners. Experts were selected from the domain of content management, SCM, and service science, from government agencies and academic institutions. Series of semi-structured interviews were conducted, and the results were transcribed and analyzed. Characteristics of the experts and the duration of the interview are shown in Table III.

The results of the content analysis and interviews were analyzed, and the SCM framework was formed based on the final elements and factors. The framework needs to be validated. Therefore, an instrument was developed based on the elements and factors that suited the context of the study. 
TABLE III

CHARACTERISTICS OF EXPERTS

\begin{tabular}{|c|c|c|c|}
\hline $\begin{array}{l}\text { Expert } \\
\text { ID }\end{array}$ & $\begin{array}{l}\text { Years of } \\
\text { Experience } \\
\text { in Related } \\
\text { Area }\end{array}$ & Position & $\begin{array}{l}\text { Duration } \\
\text { of } \\
\text { Interview }\end{array}$ \\
\hline Expert 1 & $\begin{array}{l}\text { Ten years in } \\
\text { the field of } \\
\text { ECM and } \\
\text { SCM } \\
36 \text { years in } \\
\text { total }\end{array}$ & $\begin{array}{l}\text { Strategic level with } \\
\text { the position of } \\
\text { "Head of ICT } \\
\text { Consultant in } \\
\text { Strategic field" } \\
\text { Practitioner at } \\
\text { Agency A }\end{array}$ & $\begin{array}{l}45 \\
\text { minutes }\end{array}$ \\
\hline Expert 2 & $\begin{array}{l}\text { Six years of } \\
\text { in the field of } \\
\text { ECM and } \\
\text { SCM } \\
26 \text { years in } \\
\text { total }\end{array}$ & $\begin{array}{l}\text { Tactical level with } \\
\text { the position of "ICT } \\
\text { Expert in } \\
\text { Information } \\
\text { Management" } \\
\text { Practitioner at } \\
\text { Agency B }\end{array}$ & $\begin{array}{l}50 \\
\text { minutes }\end{array}$ \\
\hline Expert 3 & $\begin{array}{l}\text { Five years in } \\
\text { the field of } \\
\text { ECM } \\
11 \text { years in } \\
\text { total }\end{array}$ & $\begin{array}{l}\text { Operational level } \\
\text { with the position of } \\
\text { "ICT Expert in } \\
\text { Information } \\
\text { Management" } \\
\text { Practitioner at } \\
\text { Agency B }\end{array}$ & 1 hour \\
\hline Expert 4 & $\begin{array}{l}\text { Eight years in } \\
\text { the field of } \\
\text { SCM } \\
11 \text { years in } \\
\text { total }\end{array}$ & $\begin{array}{l}\text { Operational level } \\
\text { with the position of } \\
\text { "Public Relation } \\
\text { Officer" Practitioner } \\
\text { at Agency C }\end{array}$ & 1 hour \\
\hline Expert 5 & $\begin{array}{l}\text { Five years in } \\
\text { the field of } \\
\text { service } \\
\text { science } \\
11 \text { years in } \\
\text { total }\end{array}$ & $\begin{array}{l}\text { Tactical level with } \\
\text { the position of } \\
\text { "Senior Lecturer." } \\
\text { Academician at } \\
\text { Institution A }\end{array}$ & $\begin{array}{l}45 \\
\text { minutes }\end{array}$ \\
\hline
\end{tabular}

\section{Instrument Development}

According to [16], one general item should be created to show the importance of each factor, besides items based on factors that reflect the context of the study. Hence, the instrument for this study consists of individual items, general items, and a "comment" column. The "comment" column allows the experts to voice their opinions and feedbacks. The questionnaire had a total of 86 items, which consisted of 11 factors that are derived from five elements as explained detail in [17].

\section{Validating the Contents using Content Validity Ratio (CVR)}

For content validity, all items in the instrument were validated using the Lawshe's technique, via the calculation of CVR. Steps to conduct the CVR calculation was adopted from [16] as stated in Fig. 3.

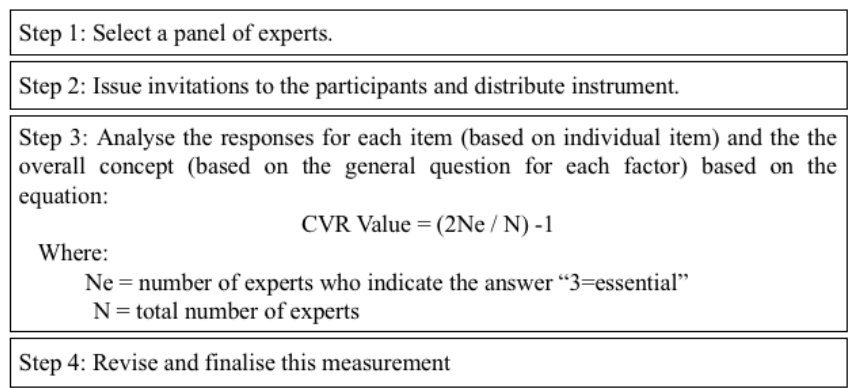

Fig. 3 Step to Conduct CVR

\section{RESULTS AND DISCUSSION}

The results and discussion of this study are detailed in the following subsections.

\section{A. Elements and Factors based on Service Science Perspective}

Service science could be interpreted as an effort to understand how systems interact and offer services to create value [18]. This approach involves active collaborations between the organizations and the customers to produce value co-creation. Service-Dominant Logic (SD-L), which is the pillar of the service science discipline, is the right formulation to identify the elements and factors that could affect SCM. From the content analysis, the elements and factors that could affect the SCM from the perspective of service science are listed in Table IV. The definition of element and factor was explained in [17].

TABLE IV

The Elements and FaCtors of SCM BASEd ON SERVICE SCIENCE PERSPECTIVE [17]

\begin{tabular}{|l|l|}
\hline Element & Factor \\
\hline \multirow{3}{*}{ Actor } & Participation \\
\cline { 2 - 2 } & Strategic implication \\
\hline \multirow{3}{*}{ Resource integration } & Operant resource \\
\cline { 2 - 2 } & Operand resource \\
\cline { 2 - 2 } & Integration \\
\hline \multirow{2}{*}{ Service exchange } & Content lifecycle \\
\cline { 2 - 2 } Institutions and & Service platform \\
\hline arrangement & Strategy \\
\cline { 2 - 2 } Service ecosystem & Governance \\
\cline { 2 - 2 } & Strategic managerial aspect \\
\hline
\end{tabular}

The importance and justification of the chosen elements in Table IV in the context of ECM and SCM are elaborated as follows:

1) Actor: The importance of actor is expressed in social media-related studies. To innovate services from the perspective of service science, organizations need to go beyond their existing roles, namely, the participation of multiple actors [19]. This condition could be linked to the activities taking place in social media interactions, namely, the involvement and interaction of various actors on the social media platform [2], [20]. Social media enables more customer involvements in assisting organizations to deliver service innovations through the process of engagement. Additionally, the importance of the actor is also expressed in previous studies of ECM. The actor in ECM is a human 
resource or personnel involved in the management of content, involving the ability, skills, and capability of the personnel [21]. Previous studies in SCM have also emphasized on the actor. [11] gave attention to the perception of managers while managing the social content. [12] had focused on the three characteristics of the actors, who are human sources directly involved in SCM.

2) Resource integration: The importance of resource integration is emphasized in previous ECM and SCM studies. Both studies give attention to knowledge and skill, which refer to the operant resource in managing content [11], [12], [22]-[24]. Additionally, the operand resource, such as technology and budget, is also important to support the management of content [12], [25].

3) Service exchange: Service exchange is essential in ECM. This is evidenced by the process of the content lifecycle, which starts by capturing content up to maintaining the content [24]. The content lifecycle is an essential element that focuses on content management that allows the value of the content to be acquired [24], [26], [27]. Also, the exchange of services requires a collaborative platform [28], [29]. Service exchange also is equally essential in SCM. The research conducted by [12] had emphasized on process and platform in managing social content.

4) Institutions and institutional arrangement: The importance of institutions and institutional arrangement is emphasised in previous ECM studies. This is evidenced by the proposed elements of strategy, governance, and strategic managerial aspects. Strategies are the planning, steps, and methods in content management [22], [24], [30]. Governance is a routine for controlling the content management in order to ensure the integrity of the content, which involves various human resources and content assets [22], [23]. Additionally, strategic managerial aspects give attention to the acceptance of actors to changes in technology, administration, and content management methods as well as the increasing level of competent actors [21]. Research in SCM has also been focusing on institutions and institutional arrangement. [12] had focused on the boundaries, such as legislation, capabilities, privacy, and ethics in enabling the management of social content.

5) Service ecosystem: The service ecosystem is essential in ECM and SCM. For example, in ECM studies, collaborative and secure environments are essential during the management of content [31]. Meanwhile, [12] proposed that SCM should take into consideration the process orientation that is involved in six main components, which are activity resources, activity environment, abridgments, affordances, ascertained boundaries, and actors.

There are significant relationships between elements and factors that derived from previous studies related to ECM and SCM as stated in the introduction (see Table II), compared to the elements and factors from the service science perspective, which explained in this study. A summary of the mapping between the elements and factors from previous studies (as stated in Table II) and from the perspective of service science is listed in Table $\mathrm{V}$.
TABLE V

MAPPING OF ELEMENTS AND FACTORS BASED ON PREVIOUS STUDIES AND THE SD-L

\begin{tabular}{|l|l|}
\hline $\begin{array}{l}\text { Elements and } \\
\text { Factors from } \\
\text { Previous Studies }\end{array}$ & Elements and Factors from SD-L \\
\hline Strategy & $\begin{array}{l}\text { Institutions and institutional } \\
\text { arrangement }\end{array}$ \\
\hline People & Actor \\
\hline Content lifecycle & Service exchange \\
\hline Technology & Resource integration \\
\hline Governance & $\begin{array}{l}\text { Institutions and institutional } \\
\text { arrangement }\end{array}$ \\
\hline $\begin{array}{l}\text { Strategic managerial } \\
\text { aspect }\end{array}$ & $\begin{array}{l}\text { Institutions and institutional } \\
\text { arrangement }\end{array}$ \\
\hline
\end{tabular}

There are several aspects seen in this study as compared to previous studies. The viewpoints are highlighted based on the following aspects:

- All related to skill and knowledge are considered in the resource integration under the operant resource.

- The actor was highlighted in this study because the actor plays a significant role in changing the patterns of communication and outreach through social media interactions. The actor has also been highlighted in previous studies on ECM. However, the study of actors in ECM studies are not specific and combined with other aspects, such as governance and strategic management [21].

- Service ecosystem focusses on the holistic environment that enables innovation via value cocreation. Therefore, in managing social content, service ecosystem is being highlighted to show the combination of the element's involved.

Service innovation is the result of active collaborations between organizations and their customers. Therefore, there is a need for a platform of engagement in order to produce the value co-creation. In this study, the DART model was adopted as an engagement platform to produce value cocreation. There are four blocks in the DART model, which are Dialogue, Access, Reflexivity, and Transparency [28]. In the context of content management, a collaboration between actors are emphasised during the process of capturing content in content lifecycle [12], [24]. Content lifecycle is a key component in the management of content. According to [24], the stages in the content lifecycle should consist of capturing, managing, analyzing, and maintaining content. Hence, in this study, service innovation was generated during the service exchange through the content lifecycle, which involved capturing the content through the interactions between actors. Similarities were observed between the stages of the content lifecycle and the blocks in the DART model, as highlighted in Table VI. 
TABLE VI

Content Life Cycle MAPPED to The DART Model

\begin{tabular}{|c|c|c|}
\hline $\begin{array}{l}\text { Content } \\
\text { Lifecycle } \\
\text { Stage }\end{array}$ & $\begin{array}{l}\text { The DART } \\
\text { Model Block }\end{array}$ & Justification \\
\hline $\begin{array}{l}\text { Capturing } \\
\text { content } \\
\text { through } \\
\text { interaction }\end{array}$ & Dialogue & $\begin{array}{l}\text { Dialogue involves a two-way } \\
\text { interaction between } \\
\text { organizations and customers. } \\
\text { In the content lifecycle, } \\
\text { capturing content was } \\
\text { conducted through the } \\
\text { interaction process between } \\
\text { both parties. }\end{array}$ \\
\hline $\begin{array}{l}\text { Managing } \\
\text { content }\end{array}$ & Access & $\begin{array}{l}\text { Highlights on how the } \\
\text { organizations and customers } \\
\text { could access the services. In } \\
\text { the content lifecycle, } \\
\text { managing content involves } \\
\text { the administration and the } \\
\text { management of content to } \\
\text { enable access to the content. }\end{array}$ \\
\hline $\begin{array}{l}\text { Analysing } \\
\text { content }\end{array}$ & Reflexivity & $\begin{array}{l}\text { A process towards providing } \\
\text { service innovation. In the } \\
\text { content lifecycle, content } \\
\text { analysis involves processing } \\
\text { the content using appropriate } \\
\text { methods, to absorb relevant } \\
\text { contents that could assist in } \\
\text { the decision-making process. }\end{array}$ \\
\hline $\begin{array}{l}\text { Maintaining } \\
\text { content }\end{array}$ & Transparency & $\begin{array}{l}\text { A provision of trust between } \\
\text { the organizations their } \\
\text { customers, which could } \\
\text { attract more customers to use } \\
\text { the services. In the content } \\
\text { lifecycle, maintaining } \\
\text { content focuses on the efforts } \\
\text { of ensuring the usability, } \\
\text { availability, and integrity of } \\
\text { the content. This is } \\
\text { imperative to gain the trust of } \\
\text { the customers. }\end{array}$ \\
\hline
\end{tabular}

The proposed elements and factors are reviewed by experts to ensure it is important in the practical environment. The results of the experts' review are described in the next subsection.

\section{B. Experts' review of Elements and Factors that Affect Social Content Management}

The importance of the proposed elements according to the experts' viewpoints are as follows:

1) Actor: The experts agreed with the participation of actors. Expert 1 stated, "Social media involve the interaction of various actors, namely from the organization and its customers. In the organization, it is important to manage the participation of actors at different managerial levels. Each level has their role. Top management is towards providing the direction, the middle management is managing the social content, while operational management is engaged directly with the citizen."

Expert 5 also stated, "Service science perspective emphasizes on the actor, especially on how the organization deal with its customers. Therefore, in SCM, it is important to manage the participation from both parties to highlight the value gained from the engagement and co-creation process."

The experts agreed with the strategic implication. Expert 2 stated, "Besides participation, the value and benefits gained from the collaboration process between the organization and its customers are important in SCM. The impact of the participation between actors brings the value to the services offered by the organization. For example, the co-creation process empowers the customer to participate in designing the services together with the organization. It shows the openness of an organization to accept the direct opinion of the customers, which is gained from the social media platform."

2) Resource integration: The experts agreed with resource integration. Expert 5 stated, "Service science emphasizes resources. The static resource is important in supporting the SCM, while the dynamic resource would make the organization different from others in the context of how the social content is being managed that is depending on skill and knowledge. Both resources need to be integrated because both resources are tied together."

From the practical viewpoint, Expert 4 stated, "To manage the social content, it involves various resources. There is a need to have the technology, budget and workforce and also skill and knowledge. Due to various resources in managing social content that involves human and content assets, the integration aspect of resources should also be considered in SCM."

3) Service exchange for service innovation: The experts agreed with the content lifecycle. Expert 4 stated, "For service innovation based on the customer's input, there is a need to follow steps starting from the capturing of content up to maintaining the content. The content needs to be managed and analyzed in order to choose the best content that could be used in the decision-making process towards offering better services to the customers."

The experts have agreed with the service platform. Expert 3 stated, "The exchange of service should take place in a good server platform or a flexible platform with a friendly interface that could facilitate the SCM. It could expedite the process of service exchange between the organization and its customers."

4) Governed by institutions and institutional arrangement: Experts also agree on this element. Expert 1 stated,"There is a need to govern the SCM. Social content is a true need of the customers that not easy to control. Customers throw their brilliant ideas on social media platform which some of them are good to consider in enhancing the services. Therefore, a strategy is important in SCM. Strategy becomes a driving force in SCM not only in managing the customers but also in internal organization. Besides that, as SCM involve various resources, so it should be governed by proper governance in order to put a control mechanism in it."

Expert 2 also stated,"Various resources need the various capability. Therefore, change management program a must in SCM."

5) A good service ecosystem: This element is also agreed with experts. Expert 4 stated, "There is a need to have a 
good service ecosystem. SCM should consider the business need of the organization, the risk, and the conducive environment. The project management mechanism also important in SCM."

From both content analysis and experts' review, the elements and factors are analyzed and refined. Then, the SCM framework based on service science perspective is developed as described in the next subsection.

\section{Social Content Management Framework based on Service Science Perspective}

The SCM framework based on service science perspective is developed as shown in Fig. 4. Fig. 4 visualizes the elements and factors that form the dimensions of the SCM framework. For illustrative purposes, "UPPERCASE" represents the element, while "sentence word" represents the factor.

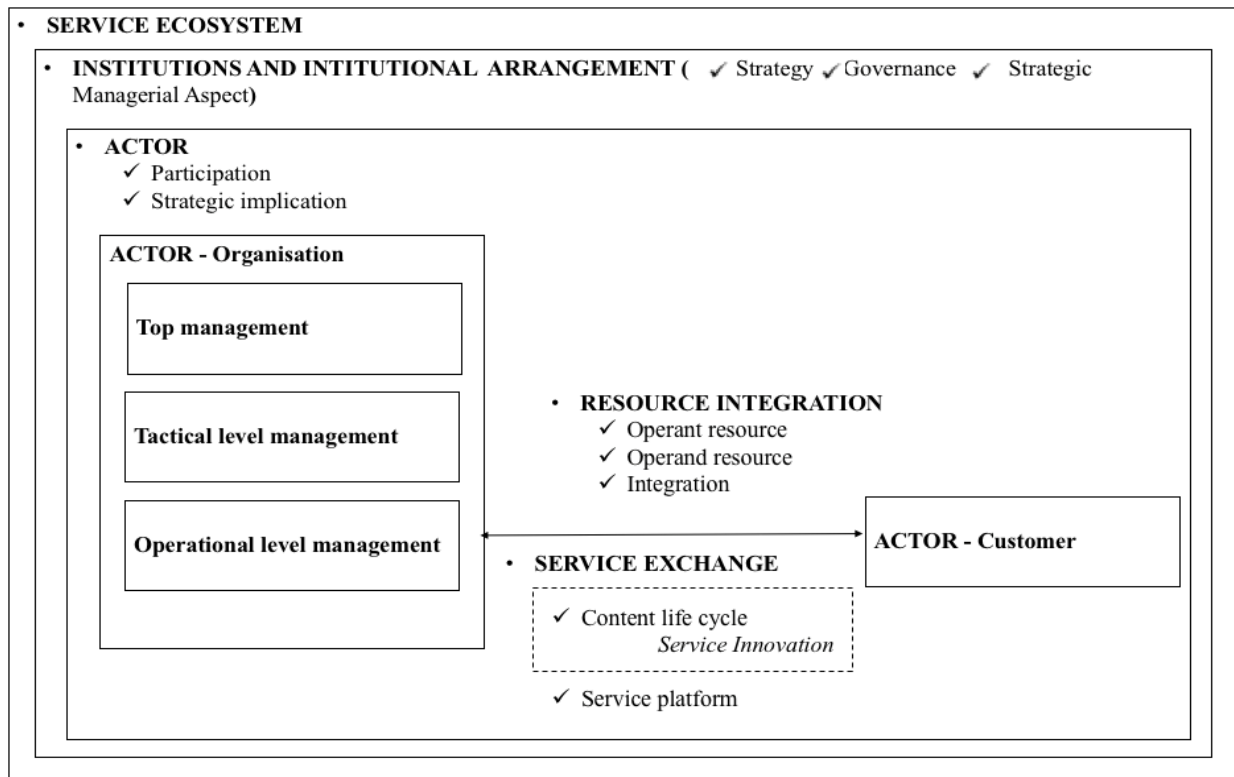

Fig. 4 Social Content Management based on Service Science Perspective

Explanation of the proposed framework is given as follows.

1) Actor: The actor plays an important role in SCM because social media interaction emphasizes the role of the actors. In SD-L, actors are the human resource who engage in value co-creation processes [32], [33]. Therefore, in this study, the actors are human resources, who involved in the value co-creation process in SCM inclusive organizations and customers. The actor in SCM could be divided into two groups, namely, the organizations and the customers. At the organizational level, three levels of management are participated in SCM, due to the different roles in managing social content, as follows:

- Top management plays a role in determining the policies and directions for SCM.

- Tactical level management plays a role in managing social content and conducts an analytical evaluation of social content.

- Operational level management engages in direct interaction with the customers during the process of capturing content and managing the social content at an early stage.

Apart from participation, strategic implication, which is the impact of participation is an essential factor. This is because, through the active collaboration between the organizations and the customers, there is a need to ensure that good returns are obtained by both parties (in the context of this study, this refers to the value co-creation).

2) Resource integration: SCM involves multiple resources that would require integration. In SD-L, resource integration is a process that prioritizes the integration of resources [34]. Therefore, in this study, resource integration involved a dynamic component in the application of resources in producing value co-creation in SCM. According to [35], the resource is a component that could benefit others. There are two resources in the SD-Logic, which are the operant resource and the operand source. To ensure innovation in services, integration between resources is important in the process of value co-creation [19].

3) Service exchange: Social media interactions between organizations and customers could pave the way for service innovation. In SD-L, service exchange is a process that enables the exchange of services through the interaction between actors to produce value co-creation [34]. Therefore, in this study, service exchange was viewed as an activity that enables the delivery of content and services based on social content acquired through direct interactions between organizations and customers. As previously mentioned, the exchange of service in content management takes place during the lifecycle of content as it involves the process of capturing content through interaction. The social content would be analyzed by the organization to obtain inputs that would help them make the right decision to innovate the offered services. This is because not all inputs from social media interactions are appropriate to the organization in the decision-making process. In the context of this study, service innovation was generated during the process of service exchange, which was through the process of the content lifecycle that consisted of four processes [24], namely: capturing content through interaction; managing content; 
analyzing content, and maintaining content. Content lifecycle takes on a good service platform, which could enhance the efficiency of service exchange and facilitates resource management.

4) Institutions and institutional arrangement: Managing social content involve various actors and content assets. Therefore, SCM needs to be regulated by institutions and institutional arrangement. In the SD-L, institutions and institutional arrangements are an assessment and governance mechanism [36]. Institutions are not organizations, but are the norms that assist the collaboration and resource integration processes, while institutional arrangements are an independent set that supports the institutions [32]. Therefore, in the context of this study, institutions and institutional arrangement, which comprised of strategy setting, sound governance, and strategic management aspects that require the involvements of actors and change management programs, are important in ensuring the continuity of the SCM.

5) Service ecosystem: Since SCM is a dynamic process, all these elements and factors need to take place in a robust service ecosystem. In SD-L, service ecosystem is a selfaligning system that integrates resources and actors, as well as linked through shared institutional arrangement and generates value through the exchange of services [34]. Therefore, in the context of this study, the service ecosystem is a holistic environment that should consider the following component:

- Organisational workflow [12].

- Systematic project management mechanism [36].

- Risk management requirement to address the expected risks [12], [37]

- Conducive environment (such as, a conducive and safe environment, adapts internal processes, increases transparency during the integration activity) [12], [22], [38].

- Active collaborations of actors [12].

- Encouragement of knowledge sharing based on the managed social content [12].

In order to validate the proposed framework, an instrument made up of a 86 items questionnaire is developed. The content validity of the instrument is reported in the next subsection.

\section{Validating the Contents of a Social Content Management Framework}

Lawshe's technique through a CVR calculation is adopted for content validity with the equation as shown in Fig. 5.

If everyone on the panel of experts indicated the answer " 3 = essential", then, the CVR value is 1.00 (all agreed).

If more than half $(>50 \%)$, but less than everyone $(<100 \%)$ on the panel of experts indicated the answer " 3 = essential", then, the CVR value is positive, ranging between 0.00 to 0.99 .

If less than half $(<50 \%)$ of the panel of experts indicated the answer " $3=$ essential", then, the CVR value is negative.

Fig. 5 Equation for CVR
Referring to [16], the answer " 2 = important (not essential)" was also important due to the positive value received. Hence, in this study, the answers of " $2=$ important (not essential)" and " 3 = essential" were considered for the calculation of CVR value for each item and each general item. This study had also specified the acceptance criteria for each item compared to the number of experts. Considering the number of experts was eight, the accepted CVR value according to [15] is a minimum value of 0.75 . It means an item that received a value of 0.75 and above should be retained in the final questionnaire. The CVR values for the individual items and general items as stated in [17] are summarized as in Table VII.

TABLE VII

CVR VALUE [17]

\begin{tabular}{|c|c|c|c|}
\hline Element & Factor & $\begin{array}{l}\text { Summary CVR } \\
\text { Value for Item }\end{array}$ & $\begin{array}{c}\text { CVR Value } \\
\text { (General } \\
\text { Item) }\end{array}$ \\
\hline \multirow[t]{2}{*}{ Actor } & Participation & $\begin{array}{c}\text { All items }=1 \\
\text { except Item No } \\
04=0.75\end{array}$ & 1 \\
\hline & $\begin{array}{l}\text { Strategic } \\
\text { implication }\end{array}$ & $\begin{array}{c}\text { All items }=1 \\
\text { except Item No } \\
20=0.75\end{array}$ & 1 \\
\hline \multirow[t]{3}{*}{$\begin{array}{l}\text { Resource } \\
\text { integration }\end{array}$} & $\begin{array}{l}\text { Operant } \\
\text { resource }\end{array}$ & \multirow[t]{3}{*}{ All items $=1$} & 1 \\
\hline & $\begin{array}{l}\text { Operand } \\
\text { resource }\end{array}$ & & 1 \\
\hline & Integration & & 1 \\
\hline \multirow[t]{2}{*}{$\begin{array}{l}\text { Service } \\
\text { exchange }\end{array}$} & $\begin{array}{l}\text { Content } \\
\text { lifecycle }\end{array}$ & \multirow[t]{2}{*}{ All items $=1$} & 1 \\
\hline & $\begin{array}{l}\text { Service } \\
\text { Platform }\end{array}$ & & 1 \\
\hline \multirow{3}{*}{$\begin{array}{l}\text { Institutions } \\
\text { and } \\
\text { institutional } \\
\text { arrangement }\end{array}$} & Strategy & \multirow[t]{3}{*}{ All items $=1$} & 1 \\
\hline & Governance & & 1 \\
\hline & $\begin{array}{l}\text { Strategic } \\
\text { managerial } \\
\text { aspect }\end{array}$ & & 1 \\
\hline $\begin{array}{l}\text { Service } \\
\text { ecosystem }\end{array}$ & $\begin{array}{l}\text { Service } \\
\text { ecosystem }\end{array}$ & All items $=1$ & 1 \\
\hline
\end{tabular}

Based on the acceptance criteria, all items are accepted for the final questionnaire. Some adjustments are done according to the comments and feedback from experts.

\section{CONCLUSIONS}

Social media interaction is significant because the customers' needs are directly collected during the process of capturing content through active interactions between the organization and its customers. Hence, social content resulting from social media interactions should be managed to ensure that the organization could produce suitable decisions based on these inputs. Social content could lead to the innovation of services offered by the organization. This article contributes to an SCM framework, from the perspective of service science. This framework is deemed to augment existing ECM frameworks.

This framework is developed based on five elements, namely, actor, resource integration, service exchange, institutions and institutional arrangement, and service ecosystem. Factors are also derived from these five elements. 
The actor is divided into factors of participation and strategic implication; the resource integration was divided into an operant resource, operand resource, and integration; the service exchange is divided into content lifecycle and service platform; while the institutions and institutional arrangement are divided into strategy, governance, and strategic managerial aspect. To innovate services, an engagement platform via the DART model was adopted, especially during the service exchange through the stages of the content lifecycle. According to the CVR value calculated, all items are accepted for the final instrument and are valid to be used for validating the framework. This framework is expected to become a reference for organizations in managing their social content.

\section{ACKNOWLEDGMENT}

Research Grant FRGS/2/2014/ICT01/UKM/02/1 supports the study. This study also supported by the Ministry of Education Malaysia, Universiti Kebangsaan Malaysia and Public Service Department of Malaysia.

\section{REFERENCES}

[1] N. S. Ahmad, R. Musa, and M. H. M. Harun, "The impact of social media content marketing (SMCM) towards brand health," in Procedia Economics and Finance, 2016, vol. 37, pp. 331-336.

[2] J. Gallaugher and S. Ransbotham, "Social media and customer dialog management at Starbucks," MIS Q. Exec., vol. 9, pp. 1389-1404, Dec. 2010.

[3] I. Golshani, "Consumer engagement factors on online social media platforms," thesis Master, Aarhus University, Sept. 2015.

[4] J. L. Gandía, L. Marrahí, and D. Huguet, "Digital transparency and Web 2.0 in Spanish city councils," Gov. Inf. Q., vol. 33, pp. 28-39, Dec. 2015.

[5] A. K. Rathore, P. V. Ilavarasan, and Y. K. Dwivedi, "Social media content and product co-creation: an emerging paradigm," J. Enterp. Inf. Manag., vol. 29, pp. 7-18, 2016.

[6] S. Mahapatra and D. Banerjee, "The new conversation : taking social media from talking to action," Havard Business Review. 2010.

[7] J. I. Criado, R. Sandoval-Almazan, and J. Ramon Gil-Garcia, "Government innovation through social media," Gov. Inf. Q., vol. 30, pp. 319-326, Nov. 2013.

[8] L. Zheng and T. Zheng, "Innovation through social media in the public sector: Information and interactions," Gov. Inf. Q., vol. 31, pp. 106-108, May. 2014.

[9] M. Kilgour, S. L., S. R. Larke, S. L. Sasser, and R. Larke, "The social media transformation process: curating content into strategy," Corp. Commun. An Int. J., vol. 20, no. 3, pp. 326-343, May. 2015.

[10] M. Liu and P. Rao, "A comparative perspective of knowledge management via social media: India and China," Learn. Organ., vol. 22, pp. 93-114, Jan. 2015.

[11] A. Herbst and J. vom Brocke, Social content management systems: challenges and potential for organizations, ser. Lecture Notes in Information Systems and Organisation, 2013, vol. 4, pp. 19-28.

[12] A. M. Aladwani, "The 6As model of social content management," Int. J. Inf. Manage., vol. 34, pp. 133-138, Apr. 2014.

[13] WAZW. Ahmad, M. Mukhtar, and Y. Yahya, Exploring elements and factors in social content management for ICT service innovation, ser. Lecture Notes on Data Engineering and Communications Technologies, 2017, pp. 851-859.

[14] WAZW. Ahmad, M. Mukhtar, and MTM. Zainuddin, "Elements affecting social content management," SOFTAM Postgrad. Symp., 2016, p. 102-108.

[15] C. Lawshe, "A quantitative approach to content validity," Pers.
Psychol., no. 1, pp. 563-575, 1975.

[16] A. Nor'ashikin, T. Alexei, and D. Whiddett, "A content validity study for a knowledge management systems success model in healthcare," J. Inf. Technol. Theory Appl., vol. 15, pp. 21-36, June. 2014.

[17] WAZW. Ahmad, M. Mukhtar, and Y. Yahya, "Validating the contents of a social content management framework," in ICEEI 17, 2017.

[18] S. L. Vargo, R. F. Lusch, and M. A. Akaka, "Advancing service science with service-dominant logic," Handb. Serv. Sci. Serv. Sci. Res. Innov. Serv. Econ., 2010.

[19] S. L. Vargo, H. Wieland, and M. A. Akaka, "Innovation through institutionalization: a service ecosystems perspective," Ind. Mark. Manag., vol. 44, pp. 63-72, 2015.

[20] X. Hao, D. Zheng, Q. Zeng, and W. Fan, "How to strengthen the social media interactivity of e-government evidence from China," Online Inf. Rev., vol. 40, no. 1, pp. 79-96, 2016.

[21] J. A. Alalwan and H. R. Weistroffer, "Enterprise content management research: a comprehensive review," J. Enterp. Inf. Manag., vol. 25, pp. 441-461, Apr. 2012.

[22] R. O'Callaghan and M. Smits, "A strategy development process for enterprise content management," in Proc. ECIS 05, 2005, p. 148160.

[23] B. E. Munkvold, T. Päivärinta, K. H. Anne, and E. Stangeland, "Contemporary issues of enterprise content management, the case of Statoil," Scand. J. Inf. Syst., vol. 18, pp. 69-100, 2006.

[24] H. a Smith and J. D. McKeen, "Developments in practice Viii: enterprise content management.," Commun. Assoc. Inf. Syst., vol. 11, pp. 647-659, 2003.

[25] P. Tyrväinen, T. Päivärinta, A. Salminen, and J. Iivari, "Characterizing the evolving research on enterprise content management," Eur. J. Inf. Syst., vol. 15, pp. 627-634, 2006.

[26] WAZW. Ahmad and M. Mukhtar, "A social content management model, based on S-D Logic," in Proc. ACIS 16, 2016, p. 274-281.

[27] WAZW. Ahmad and M. Mukhtar, "A Social Content Management Model, based on the DART Model," Am. J. Appl. Sci., vol. 14, pp. 25-33, Jan. 2017.

[28] V. Ramaswamy and K. Ozcan, The co-creation paradigm. Stanford University Press, 2014.

[29] J. Bertot, E. Estevez, and T. Janowski, "Universal and contextualized public services: Digital public service innovation framework," Gov. Inf. $Q$., vol. 33, pp. 211-222, 2016.

[30] S. Hullavarad, R. O'Hare, and A. K. Roy, "Enterprise content management solutions: roadmap strategy implementation challenges," Int. J. Inf. Manage., vol. 35, pp. 260-265, Jan. 2015.

[31] B. Aziz, G. Cortese, B. Crispo, and S. Causetti, "A secure and scalable grid-based content management system," in Proc. ICARS 10, 2010, p. 404-409.

[32] H. Wieland, K. Koskela-Huotari, and S. L. Vargo, "Extending actor participation in value creation: an institutional view," J. Strategy. Mark., vol. 24, no. 3-4, pp. 210-216, Dec. 2015.

[33] S. P. Singaraju, Q. A. Nguyen, O. Niininen, and G. Sullivan-Mort, "Social media and value co-creation in multi-stakeholder systems: a resource integration approach," Ind. Mark. Manag., vol. 54, pp. 4455, Jan. 2016.

[34] S. L. Vargo and R. F. Lusch, "Institutions and axioms: an extension and update of service-dominant logic," J. Acad. Mark. Sci., vol. 44, pp. 5-23, 2016.

[35] R. F. Lusch and Satish Nambisan, "Service innovation: a servicedominant logic perspective," MIS Q., vol. 39, pp. 155-176, Mar. 2015.

[36] S. Dhouib and R. Ben Halima, "Surveying collaborative and content management platforms for enterprise," in Proc. IEEE 13, 2013, p. 299-304.

[37] D. Miles, "Managing social content - to maximize value and minimize risk," 2011.

[38] T. Le Dinh, T. a. Rickenberg, H.-G. Fill, and M. H. Breitner, "Enterprise content management systems as a knowledge infrastructure:" Int. J. e-Collaboration, vol. 11, pp. 49-70, Jul. 2015. 